\title{
Phytoprotection
}

\section{Weed community ecology : Tedious sampling or relevant science? A Canadian perspective}

\section{D.A. Derksen}

Volume 77, numéro 1, 1996

URI : https://id.erudit.org/iderudit/706098ar

DOI : https://doi.org/10.7202/706098ar

Aller au sommaire du numéro

Éditeur(s)

Société de protection des plantes du Québec (SPPQ)l

ISSN

0031-9511 (imprimé)

1710-1603 (numérique)

Découvrir la revue

Citer cet article

Derksen, D. (1996). Weed community ecology : Tedious sampling or relevant science? A Canadian perspective. Phytoprotection, 77(1), 29-39.

https://doi.org/10.7202/706098ar
Résumé de l'article

L'étude de l'écologie des communautés de mauvaises herbes implique des aspects de types d'espèces, de diversité et de variabilité spatiale et temporelle. Auparavant, la recherche canadienne dans ce secteur mettait l'accent sur les inventaires de mauvaises herbes, alors que la recherche a plus récemment porté sur la composition des communautés résultant des méthodes de travail du sol et des rotations. De nouvelles techniques d'analyse multivariée ont été utilisées afin d'analyser les mauvaises herbes à l'échelle de la communauté plutôt que celle de l'espèce, d'où une nouvelle compréhension de la dynamique des communautés. Quoique l'étude de l'écologie des communautés de mauvaises herbes implique souvent des échantillonnages laborieux, l'accroissement des efforts de recherche dans ce secteur devrait procurer les bases nécessaires au développement de stratégies efficaces de lutte intégrée contre les mauvaises herbes. Cet article présente les aspects de l'écologie des communautés de mauvaises herbes à la lumière de la recherche canadienne, et formule des recommandations pour de futures démarches de recherche. 
Symposium on Weed Ecology

Expert Committee on Weeds - Edmonton 1993

Symposium sur l'écologie des adventices

Comité d'experts en malherbologie - Edmonton 1993

\title{
Weed community ecology : Tedious sampling or relevant science? A Canadian perspective
}

\author{
Douglas A. Derksen
}

Received 1995-07-14; accepted 1996-05-02

The study of weed community ecology involves aspects of species life forms, diversity, and spatial and temporal variability. Previously, Canadian research in this area focused on weed surveys, while recent research has been conducted on community composition as influenced by tillage system and crop rotation. New techniques in multivariate ordination have been used to analyse weeds at a community rather than a species level, with a resultant new understanding of community dynamics. Although the study of weed community ecology often involves tedious sampling, increased research in this area would provide the basis for the development of effective integrated weed management strategies. This paper discusses aspects of weed community ecology in light of Canadian research and makes recommendations for future studies.

Derksen, D.A. 1996. Écologie des communautés de mauvaises herbes : échantillonnage fastidieux ou science pertinente? Une perspective canadienne. PHYTOPROTECTION 77 : 29-39.

L'étude de l'écologie des communautés de mauvaises herbes implique des aspects de types d'espèces, de diversité et de variabilité spatiale et temporelle. Auparavant, la recherche canadienne dans ce secteur mettait l'accent sur les inventaires de mauvaises herbes, alors que la recherche a plus récemment porté sur la composition des communautés résultant des méthodes de travail du sol et des rotations. De nouvelles techniques d'analyse multivariée ont été utilisées afin d'analyser les mauvaises herbes à l'échelle de la communauté plutôt que celle de l'espèce, d'où une nouvelle compréhension de la dynamique des communautés. Quoique l'étude de l'écologie des communautés de mauvaises herbes implique souvent des échantillonnages laborieux, l'accroissement des efforts de recherche dans ce secteur devrait procurer les bases nécessaires au développement de stratégies efficaces de lutte intégrée contre les mauvaises herbes. Cet article présente les aspects de l'écologie des communautés de mauvaises herbes à la lumière de la recherche canadienne, et formule des recommandations pour de futures démarches de recherche.

1. Agriculture and Agri-Food Canada, Research Station, Box 1000A, R.R. 3, Brandon, Manitoba, Canada R7A 5 Y3 


\section{INTRODUCTION}

Research on the biology and ecology of weeds has been conducted primarily on the biology of specific weed species, on the competitive effects of one species on a crop, and on the control of a single problem weed within a crop. Less research has been conducted at the community level due to the physical scale required by this type of research, the large and complex databases involved, and the ongoing search for simple ways to describe complex systems using data analysis and comparison. Historically, the effects of agronomic practices on weed communities have generally been understood, but much of the information has been anecdotal. There has been a new emphasis on weed community ecology research in Canada during the past $5 \mathrm{yr}$; however, this area of study has not been a specific concern of the Canadian Expert Committee on Weeds (ECW). ECW is comprised of weed scientists from government, university, and industry with a mandate to review weed research. In the past, the committee has primarily focused on herbicides. Considering the new effort to include weed ecology in ECW, this paper will provide a background on aspects of community ecology, discuss Canadian research in weed community ecology, and evaluate the current and potential impact of weed community ecology on practical agriculture.

Weed community ecology is the study of a group of weed species within a defined area, such as a regional soil zone, farm field, or area within a field. Research in weed community ecology encompasses the study of the impact of agronomic practices, such as crop rotation, on weed communities and the impact of weed communities on crop yield and long-term management. Confusion has arisen around the terms "community" and "population". For example, weed population changes have been mentioned in relation to changing tillage practices when weed communities should be referred to. Population refers to the species level including distinct bio- and ecotypes whereas, in this case, the term community would include the effect of tillage practices on all species.
Initially, research in plant community ecology was based on description and theory, with a discussion of succession, composition, and associations by Clements, Gleason, Braun-Blanquet, and Du Rietz (Noy-Meir and van der Maarl 1987). The second phase of community ecology has been more quantitative and has also included greater emphasis on the mechanisms or processes. Scientists such as Grubb, Harper, de Wit, and Tilman brought forward and refined the concepts of micro sites, neighbourhoods, and competition. Furthermore, research has become less observational and more experimental. As an example, hypotheses relating community composition within different fields to management variables have been tested using ordination and correlation techniques (ter Braak 1987). This approach has recently been used on data derived from structured experiments (Derksen et al. 1993; Légère et al. 1993; Salonen 1993). Future research in community ecology will continue to have a greater emphasis on experimentation (Keddy 1987).

Canadian plant ecologists have made a valuable contribution to the study of general plant ecology by utilizing the less disturbed habitat of pastures or old fields that simulate natural communities (Turkington 1989). This paper focuses on the study of weed ecology in the more disturbed habitat of farming systems that include the production of annual crops. In these situations, plant communities respond to both ecological processes and agronomic disturbances.

The formalized study of weed community ecology within farming systems in Canada began with weed surveys by Fletcher (1897), Groh and Frankton (1949), Alex (1966), and more recently by Thomas who has published numerous survey reports and scientific papers (Thomas 1991; Thomas and Donaghy 1991; Thomas and Ivany 1990; Thomas and Wise 1987; Thomas et al. 1994). Surveys have provided useful information to farmers, extension agronomists, and the agricultural industry at large. The data from surveys have been used to justify the expenditure of private and public research funds. Research energies have been mobilized to address weed problems such 
as quackgrass [Agropyron repens (L.) Beauv.] and wild oats (Avena fatua L.) through the formation of action committees within ECW. Furthermore, farmers have been alerted to new weed problems by survey data that has documented the invasion and spread of new weeds, such as downy brome (Bromus tectorum L.) (Douglas et al. 1990).

Weed scientists have also moved from a descriptive approach of weed communities to a more quantitative approach of data analysis, and from data based on sampling fields to experimental data (Table 1). Dale et al. (1992) correlated weed community composition with environmental and management factors using survey data from Thomas. They determined that community composition was affected by soil type and previous crop to a greater extent than by management practices. Multivariate statistical techniques typically used to analyse data sampled from fields has recently been used in Canada to evaluate community differences among crop production systems based on data from large-scale structured experiments (Derksen et al. 1993, 1994; Légère et al. 1993).

Noy-Meir and van der Maarl (1987) provide a useful template to discuss plant community ecology. They divide the study of vegetation science into four aspects: i) species life forms, ii) diversity and dominance, iii) spatial variability, and iv) temporal variability. Following is a discussion of each aspect using Canadian examples in weed ecology.

\section{SPECIES LIFE FORMS}

Research in weed community ecology can be conducted to ascertain whether agronomic practices influence the proportion of species present with certain life forms, such as summer annual, winter annual, biennial, and perennial habits. Changes in the proportion of species

Table 1. Recently published Canadian research studies in weed community ecology

\begin{tabular}{|c|c|c|c|}
\hline $\begin{array}{l}\text { Ecological } \\
\text { aspect }^{\mathrm{a}}\end{array}$ & $\begin{array}{l}\text { Agronomic } \\
\text { practices }^{b}\end{array}$ & References & Comments ${ }^{c}$ \\
\hline Sv & $\mathrm{Ts}, \mathrm{Cr}$ & Benoit et al. 1992 & community analysis (CDA), mapping \\
\hline Sv & $\mathrm{Ts}, \mathrm{Cr}$ & Blackshaw 1994 & analysis by species \\
\hline Sv, Dd & $\mathrm{Cr}$ & Dale and Thomas 1987 & dendrograms, cluster analysis \\
\hline Sv & $\mathrm{Ts}, \mathrm{Cr}$ & Dale et al. 1992 & canonical correspondence analysis (CCA) \\
\hline Lf, Sv, Tv & $\mathrm{Ts}, \mathrm{Cr}$ & Derksen et al. 1993 & community analysis (CDA) \\
\hline Sv, Tv & $\mathrm{Ts}, \mathrm{Cr}$ & Derksen et al. 1994 & community analysis (CDA) \\
\hline Sv, Tv & $\mathrm{Ts}, \mathrm{Cr}$ & Derksen et al. 1995 & community analysis (CDA), diversity indices \\
\hline Sv & $\mathrm{Tr}, \mathrm{Cr}$ & Frick and Thomas 1993 & community analysis (RDA) \\
\hline Sv, Tv & $\mathrm{Ts}, \mathrm{Cr}$ & Hume 1982 & community analysis (PCA) \\
\hline Tv & $\mathrm{Ts}, \mathrm{Cr}$ & Hume et al. 1991 & analysis by species \\
\hline Sv & $\mathrm{Ts}, \mathrm{Cr}$ & Izaurralde et al. 1993 & analysis by species \\
\hline Sv & $\mathrm{Ts}, \mathrm{Cr}$ & Légère et al. 1993 & community analysis (CDA) \\
\hline Sv & $\mathrm{Ts}, \mathrm{Cr}$ & Thomas and Wise 1987, 1988 & analysis by species \\
\hline Sv, Dd & $\mathrm{Ts}, \mathrm{Cr}$ & Thomas 1991 & Lorenz curves \\
\hline Sv & $\mathrm{Ts}, \mathrm{Cr}$ & Thomas and Donaghy 1991 & analysis by species \\
\hline Sv & $\mathrm{Ts}, \mathrm{Cr}$ & Thomas et al. 1994 & analysis by species \\
\hline Sv & $\mathrm{Ts}, \mathrm{Cr}$ & Thomas and Ivany 1990 & community analysis \\
\hline
\end{tabular}

a Sv: spatial variability; Dd: diversity and dominance; Lf: species life form; Tv: temporal variability.

b Ts: tillage system; Cr: crop rotation.

- CDA : canonical discriminant analysis; CCA : canonical correspondence analysis; RDA : redundancy analysis; PCA : principal component analysis. 
exhibiting one life form may necessitate a change in weed management strategy. For example, if more farmers use standing stubble as a method to trap snow thus reducing soil disturbance, greater emphasis may be required on managing winter annual weeds and short-lived perennial species, such as scentless chamomile (Matricaria inodora L.).

Derksen et al. (1993) tested the hypothesis that weed communities in zero- and minimum-tillage systems would have more perennial species, more annual grass species, more volunteer crops as weeds, more wind-dispersed species, and fewer annual broadleaf species than conventional-tillage systems (Froud-Williams et al. 1983). These predictions were based on European experiences in the 1970s, prior to the advent of selective graminicides and the widespread usage of glyphosate [N-(phosphonomethyl)glycine]. The results of 13 station-years of data in eastcentral Saskatchewan indicated that not all these predictions were borne out (Derksen et al. 1993). Quackgrass, Canada thistle [Cirsium arvense (L.) Scop.], and perennial sow-thistle (Sonchus arvensis L.), three creeping perennials that reproduce vegetatively, were found in similar abundance in all tillage systems, while foxtail barley (Hordeum jubatum L.), and dandelion (Taraxacum officinale Weber), two simple perennials reproducing from wind-blown seed, were strongly associated with zero tillage. Wild oats, a summer annual weed in this area, was associated with zero tillage in some instances, but green foxtail [Setaria viridis (L.) Beauv.] was not. Annual broadleaf and perennial species with wind-blown seeds were generally more frequent in zero tillage. Volunteer crops occurred in greater abundance in zero tillage. Some annual broadleaf weeds, such as wild mustard (Sinapis arvensis L.), were more abundant in zero tillage, but most were not. Grouping species by perennation, as in this study, does not adequately explain community dynamics.

Night-flowering catchfly (Silene noctiflora L.), typically a summer annual in western Canada, has been observed to overwinter in zero-tillage fields. Unconfirmed reports of cleavers (Gallium aparine L.) and stork's bill [Erodium cicutar- ium (L.) L'Her.] also being winter annuals in zero tillage have occurred. Research is required to determine if these species are overwintering due to the insulating effect of snow trapped in crop stubble or to the lack of fall or spring tillage in zero tillage, and if reduced-tillage systems are selecting for "winter annual" plants within the ambient populations of some typically summer annual weed populations. Management strategies need to be developed to deal with the expression of life forms previously not encountered within a crop production area.

\section{DIVERSITY AND DOMINANCE}

A formal analysis of community diversity involves the measurement of species richness and evenness (Magurran 1988). Species richness assesses the number of species within a community and evenness is an assessment of their proportional or relative abundance. Community structure refers to the organization of a community as determined by the relative abundance of species (Clements et al. 1994). Weed community diversity studies have been conducted in Europe (Mahn 1984; Topham and Lawson 1982), and more recently in Canada. From agricultural field survey data, Thomas (1991) used Lorenz curves to show that weed community diversity in Saskatchewan, Manitoba, and North Dakota was similar. All of these communities were dominated by a few species.

Derksen et al. (1995) recently used diversity indices and dominance-diversity curves to evaluate the impact of postemergence herbicides on weed communities within zero-, minimum-, and conventional-tillage systems. To do this, weed community diversity was evaluated just prior to postemergence herbicide application and 6-8 wk later. Species richness and evenness were found to increase slightly following herbicide application due to a reduction in abundance of the dominant species. These findings may have practical significance. An annual application of broad-spectrum herbicides may lead to an increase in comımunity evenness due to the greater relative abundance of rare species. Varied selec- 
tion pressure through the use of different herbicides or cropping patterns may have to be employed to avoid selecting for difficult-to-control rare weed species.

The practical significance of weed community diversity needs to be determined. For example, is diversity desirable from an integrated weed management (IWM) perspective? Weed diversity may be beneficial for insect management (Altieri 1994), but what impact does weed diversity have on weed management? Clements et al. (1994) have postulated that a diverse weed community that does not reduce crop yield may be beneficial; however, this has not been proven. The question remains : Does community evenness have greater practical significance than the composition of species within a community?

\section{SPATIAL VARIABILITY}

Spatial variability in weed community composition can be evaluated at a landscape scale such as that of a soil zone (Dale et al. 1992) or at a field scale (Hume and Archibold 1986).

Thomas (1985) mathematically defined relative abundance as a measure of spatial variability within and between agricultural fields for use in provincial weed surveys. Determining variation among fields within a wide geographic area has given rise to an understanding of the relative abundance of weed species, their distribution, and their pattern of spread (Douglas et al. 1990; Thomas 1985). Furthermore, documenting the spatial variability of weed communities on this scale can provide new insights into their response to agronomic manipulations (Dale et al. 1992), because environmental gradients present within a broad geographic area are greater than gradients present within structured agronomic experiments.

Within-field variation has significant implications for crop loss threshold values (Brain and Cousens 1990). The considerable variation in community composition, density, and relative times of weed emergence present within the large fields of western Canada may impede the implementation of economic thresholds as a decision support tool for farmers. Recently, Johnson et al. (1995) suggested that the use of intermittent herbicide application systems in row-crop corn production could reduce herbicide usage if coupled with weed distribution maps or plant sensing equipment. In Canada, Benoit et al. (1992) have demonstrated the use of field mapping to illustrate the spatial distribution of weed species within the seed bank. Although detect-spray application systems have been tested and used in non-crop situations in Canada (Blackshaw 1994), these systems have not been used within crops or in conjunction with weed distribution maps.

\section{TEMPORAL VARIABILITY IN COMIMUNITIES}

Community compositional changes occur from season to season and throughout a season. Quantifying differences from season to season may lead to an understanding of principles involved in community compositional change. Quantifying compositional differences during a season may lead to a better understanding of the effects of agronomic practices on community dynamics. Data has been collected to address temporal changes in weed communities from mid- to long-term crop management studies in Canada (Table 1).

Past research conducted in structured experiments on the impact of agronomic factors on compositional differences in weed communities has been limited by the analytical tools available. In early research, mean density values were presented for each species or univariate analyses of variance were conducted (Froud-Williams et al. 1983). Although these approaches are useful, differences between treatments are often difficult to determine due to the inherent variation present within natural weed communities. Furthermore, species of low density or rare species are often overlooked, although these may be harbingers of future problems. Multivariate analytical techniques have overcome many of these problems (Digby and Kempton 1987; ter Braak 1987) and have recently been used to analyse weed communities in their entirety (Table 1). 
One of the first Canadian papers to compare the composition of communities using these techniques was published by Hume (1982). The impact of fertilizer within wheat fallow rotations on weed communities in Saskatchewan was determined using principal component analysis (PCA). The findings indicated that fertilization and crop frequency altered community composition. Green foxtail densities were highest in fertilized plots and Canada thistle densities were greater in continuous cropping.

Frick and Thomas (1993) used redundancy analysis (RDA) to examine the effects of crop, tillage system, and year on weed community composition in conservation-tillage systems in south-western Ontario. They found that crop and year had a greater effect on composition than tillage system and that the weed community in corn was more similar to soybeans than wheat.

Canonical discriminant analysis (CDA) has been used by Derksen et al. (1993, 1994) and Légère et al. (1993) to evaluate the impact of tillage systems on weed communities. Compositional differences at sites in east-central Saskatchewan were explained to a greater degree by crop rotation and year to year variations than by tillage systems (Derksen et al. 1994). In Quebec, there was an interaction between tillage system and soil $\mathrm{pH}$ (Légère et al. 1993). The discrimination among tillage systems was based on grass weeds in the more acidic soil, and as the $\mathrm{pH}$ increased discrimination was based on broadleaf weeds.

Biplots can be generated from PCA, RDA, CDA, and other multivariate analytical techniques to illustrate results (ter Braak 1987). Biplots use ordination functions as axes and generally consist of a vector diagram of species and/or environmental variables, and a cluster diagram of sites or plots. For example, the biplot in Figure 1 was created from an RDA of $3 \mathrm{yr}$ of data to determine the relationship of species composition with tillage system over time. In ordination diagrams, axis 1 explains the greatest proportion of variation. In this case, since the greatest distance between 1989 and the years 1988 and 1990 is in the horizontal direction, the composition of weed communities was affected to the greatest extent by yearly variations. Tillage system differences occurred in the vertical direction (along axis 2), therefore, year to year variability in environmental conditions had a greater impact on weed communities than did tillage system.

The association of weed species with year or tillage system can be determined by the length and direction of species vectors. For example, wild mustard, volunteer canola (Brassica napus L.), and flixweed [Descurainia sophia (L.) Webb] were associated with the year 1988 and zero tillage with wild mustard and volunteer canola most strongly associated with zero tillage (Fig. 1). Since 1988 was a drought year, a new hypothesis could be generated from this diagram that weed communities in zero tillage have the potential to change towards communities evident in drought years. This may be plausible due to reduced crop competition in drought years allowing rare species to become evident. The findings illustrated by this figure add credence to the concept that crop competition against weeds is of particular importance in reduced-tillage systems (Derksen et al. 1994).

Temporal changes in weed communities within a season impact on weed seed rain and crop-weed competition. Some species may complete their life cycle before the emergence of a crop while others complete theirs after crop harvest. For example, in western Canada, species such as pygmy flower (Androsace septentrionalis L.), wood whitlow-grass (Draba nemorosa L.), and downy brome can complete their life cycle before late-seeded summer annual crops are sown. Species such as night-flowering catchfly and scentless chamomile [Matricaria maritima L. var. agrestis (Knaf) Wilrnott] have been observed to establish after the application of postemergence herbicides within summer annual crops and can complete their life cycle prior to harvest, after harvest, or the following spring. These regenerative strategies (Grime 1979) ensure that the seed bank is not depleted, and should agronomic practices change, these species may present agronomic problems. More research on community dynamics throughout a grow- 


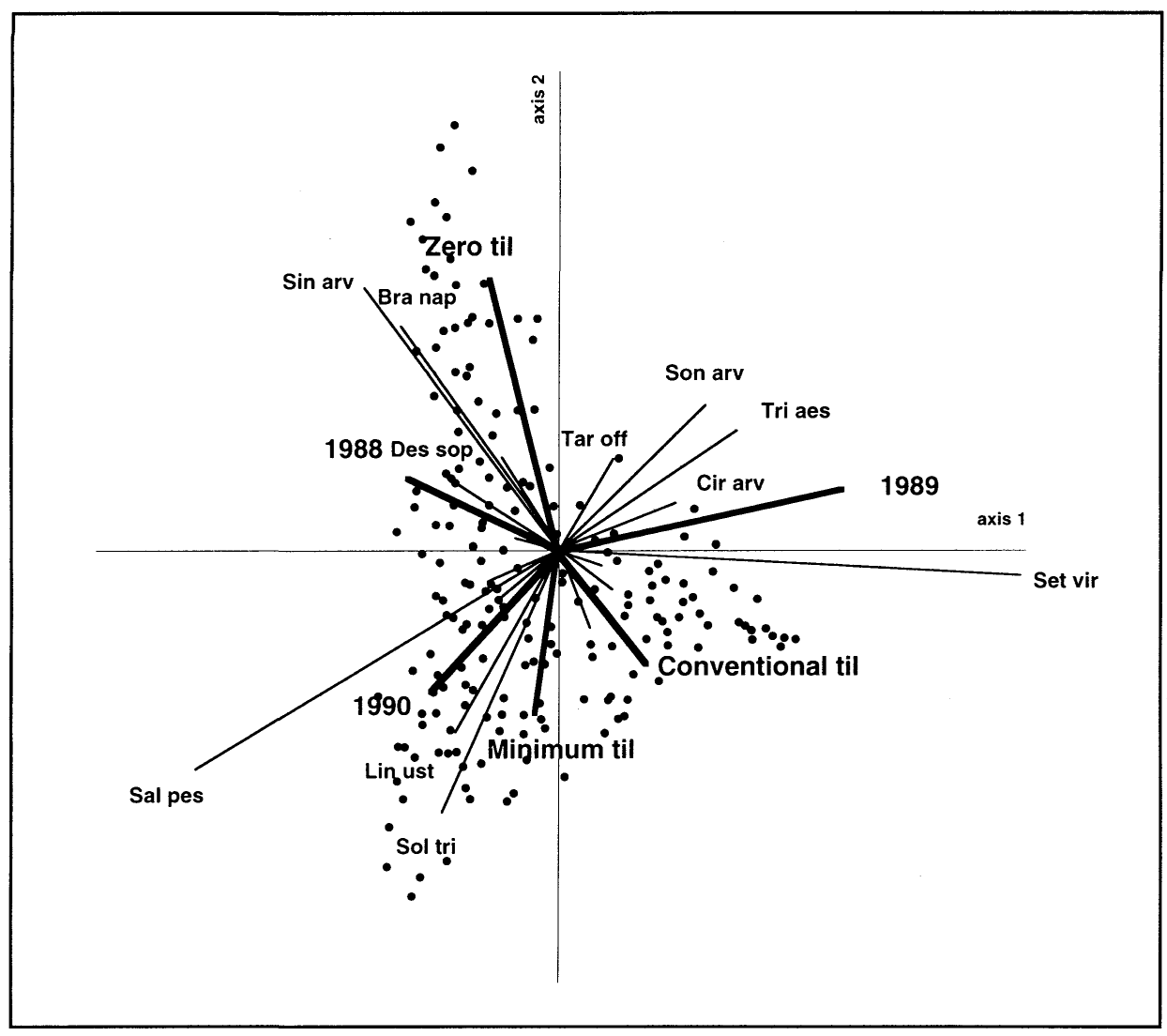

Figure 1. RDA ordination diagram of weed communities in zero-, minimum-, and conventionaltillage systems from 1988 to $1990(F<0.05)$ based on Monte Carlo simulation. Analysis conducted with CANOCO (Mirocomputer Power, Ithaca, NY). The symbols represent individual plots. Biplot scaling was used for tillage system, year, and species vectors (see Derksen et al. 1993 for CDA analysis of data by year). The direction and length of the vectors indicates the degree of association between weed species, year, and tillage system. Abbreviations: Bra nap = Brassica napus, Cir arv = Cirsium arvense, Des sop = Descurainia sophia, Lin ust = Linum usitatissimum, Sal pes = Salsola pestifera, Set vir = Setaria viridis, Sin arv = Sinapis arvensis, Sol tri = Solanum triflorum, Son arv = Sonchus arvensis, Tar off = Taraxacum officinale, Tri aes = Triticum aestivum (spring). (D. Derksen and G. Lafond, unpublished data) 
ing season would lead to an understanding of the mechanisms involved in weed community change over time.

Temporal variability in weed emergence in relation to crop emergence can affect competitive ability of weed species and resultant crop yield losses (O'Donovan 1996). Although research on the relative timing of weed emergence is generally done with one weed species, $M$. Leblanc and D. Cloutier (personal communication) have recently undertaken research to detect the population emergence patterns of a weed community present within corn. Initial results show that peak emergence of annual grasses and broadleaf weeds occurs at different times than perennial species arising from vegetative propagules. If this is generally the case, then herbicide tank mixtures applied to control a broad spectrum of weeds may not be as effective as several herbicide applications to different cohorts within a community. More research is required to predict the recruitment patterns of species within weed communities so that farmers can enhance the effectiveness of IWM programs, particularly those using reduced herbicide rates.

Temporal changes through time can lead to successional changes in weed communities. The causes of successional changes are complex, therefore, succession has been viewed hierarchically to provide a template to understand the causes, processes, and defining factors involved. This approach has recently been applied to weed community changes in conservation-tillage systems (Swanton et al. 1993).

If the changes within weed communities occurring as the result of reduced tillage are due to successional (directional) rather than fluctuational (non-directional) change, then weed management strategies may have to be modified. Fluctuational changes in relative community composition due to the interaction of agronomic practices and environmental constraints may be easier to deal with than a directional change. Fluctuational change is the result of varied agronomic practices that can result in a species in- creasing in abundance in some years and decreasing in others, while directional change toward difficult to control species, such as perennial weeds, leads to increasing weed management problems. Diverse agricultural practices, such as the use of herbicides, tillage, and crop rotations, may act to inhibit directional change. The use of herbicides in conjunction with crop rotation may have created enough variation in agronomic practices to inhibit directional changes in zero tillage in one study (Derksen et al. 1995) while the lack of diverse agronomic practices used in other studies may explain a directional change toward perennial species (Moyer et al. 1994).

Annual fluctuations in weed community composition must be considered when evaluating research trials. Assumptions that sampling in the final year of a long-term project will show the end result of a continuum of change may not be appropriate. In order to understand temporal changes in weed communities, frequent, preferably annual, community evaluations are required.

In the past, research in weed community ecology, other than weed survey information, has had a limited impact on practical agriculture, but this has recently changed. Information on weed community dynamics in conservation-tillage systems derived from multivariate analysis of weed community data is currently being transferred to extension personnel, farmers, and agri-businesses, and is being readily adopted in order to improve the sustainability of these crop-production systems. The principle of reducing selection pressure in conservation-tillage systems through the use of diverse agronomic practices, such as crop rotations and different times of herbicide application has been developed into a farm level information package (Derksen 1995). In the future, basic and practical information derived from research in weed community ecology may have a greater impact when disseminated through decision support and expert systems that focus on a systems approach to weed management. These types of production tools are currently being developed in Canada. 


\section{RECOMMENDATIONS}

A greater understanding of weed community dynamics at an empirical and mechanistic level, and an understanding of the interaction of ecological and agronomic factors would enhance our ability i) to generate and test agroecological principles, ii) to develop integrated weed management strategies, iii) to predict weed community changes, and iv) to test the implications of agronomic practices on the long-term sustainability of agriculture. Other than an evaluation of weed communities in long-term agronomy studies, there is currently little Canadian research in weed ecology focused at the community level. Therefore, the following recommendations are made:

1. Weed ecologists should be involved in the planning of long-term agronomy trials. This would ensure that proper data are accumulated and that confounding experimental effects are reduced. Existing information from long-term studies should be compiled into a report and the data subjected to community analysis where possible.

2. Research on the relationship among weed seed banks, seedling recruitment, plant establishment, and seed production must be undertaken to understand the mechanisms driving the dynamics of weed populations within the context of weed communities and crop production systems.

3. Given the patchy nature of weed species distribution within weed communities, there is a need to establish a weed community sampling protocol for use in agronomic trials, farm field surveys, and crop loss threshold models. The potential exists to use weed community mapping and computerassisted herbicide application to reduce herbicide use.

4. There is a need to further explore analytical tools currently being developed and utilized within general vegetation science for use in agricultural situations and to adopt these techniques, where possible, for use in structured experiments. The relative merits of principal components analysis
( $P C A)$, redundancy analysis (RDA), canonical discriminant analysis (CDA), etc., need to be ascertained.

5. There is a need for more research on the interaction of environmental variation, agronomic practices, and ecological processes on weed community composition and changes over time in order to increase our ability to predict changes in weed communities, especially in reduced-tillage, reducedinput, and organic farming systems.

6. Research on the long-term effects of weed community diversity on crop production is required to determine the practical significance of greater or lesser weed species richness and evenness on weed management.

An analysis of the effects of management system, tillage system, crop rotation, and input level on weed communities comes at a crucial time when there is an increased interest in the use of integrated weed management practices. Determining potential changes in weed composition would allow farmers and researchers the opportunity to develop new approaches to weed management. For example, weed management strategies could be developed that inhibit undesirable changes, promote desirable changes, or that minimize the negative effect of weed community changes on crop yield.

\section{ACKNOWLEDGEMENTS}

The helpful suggestions and insights emerging from the critical review of this paper by A.G. Thomas and E.E. Regnier were gratefully appreciated.

\section{REFERENCES}

Alex, J.F. 1966. Survey of weeds on cultivated land in the prairie provinces. Exp. Farm Res. Branch, Canada Department of Agriculture, Regina, Saskatchewan. 68 pp.

Altieri, M.A. 1994. Biodiversity and pest management in agroecosystems. Food Products Press, Binghamton, New York. $185 \mathrm{pp}$. 
Benoit, D.L., D.A. Derksen, and B. Panneton. 1992. Innovative approaches to seedbank studies. Weed Sci. $40: 660$ 669.

Blackshaw, R.E. 1994. Detectspray-S45: a new concept in sprayer technology. Proc. Soil Conserv. Workshop, Edmonton, Alberta. Pages 167-169.

Brain, P., and R. Cousens. 1990. The effect of weed distribution on predictions of yield loss. J. Ecol. 27 : 735-742.

Clements, D.R., S.F. Weise, and C.J. Swanton. 1994. Integrated weed management and weed species diversity. Phytoprotection $75: 1-18$.

Dale, M.R.T., and A.G. Thomas. 1987. The structure of weed communities in Saskatchewan fields. Weed Sci. 35 : 348355.

Dale, M.R.T., A.G. Thomas, and E.A. John. 1992. Environmental factors including management practices as correlates of weed community composition in spring seeded crops. Can. J. Bot. 70 : 1931-1939.

Derksen, D.A. 1995. Towards a new understanding of weed management in zerotillage systems. Pages 192-199 in: Proc. West. Canada Agron. Workshop. Red Deer, Alberta.

Derksen, D.A., G.P. Lafond, A.G. Thomas, H.A. Loeppky, and C.J. Swanton. 1993. The impact of agronomic practices on weed communities: tillage systems. Weed Sci. 41 : 409-417.

Derksen, D.A., A.G. Thomas, G.P. Lafond, H.A. Loeppky, and C.J. Swanton. 1994. The impact of agronomic practices on weed communities : fallow within tillage systems. Weed Sci. 42 : 184-194.

Derksen, D.A., A.G. Thomas, G.P. Lafond, H.A. Loeppky, and C.J. Swanton. 1995. The impact of herbicides on weed community diversity within conservation-tillage systems. Weed Res. 35 : 311-320.

Digby, P.G.N., and R.A. Kempton. 1987. Multivariate analysis of ecological communities. Chapman and Hall, London. 206 pp.

Douglas, B.J., A.G. Thomas, and D.A. Derksen. 1990. Downy brome (Bromus tectorum) invasion into southwestern Saskatchewan. Can. J. Plant Sci. 70 : 11431151.

Fletcher, J. 1897. Weeds. Canada Department of Agriculture, Ottawa, Ontario. Bull. 28. $43 \mathrm{pp}$.
Frick B.L., and A.G. Thomas. 1993. Influence of tillage systems on weed abundance in southwestern Ontario. Weed Technol. 7 : 699-705.

Froud-Williams, R.J., D.S.H. Drennan, and R.J. Chancellor. 1983. Influence of cultivation regime on weed floras of arable cropping systems. J. Appl. Ecol. 20:187197.

Grime, J.P. 1979. Plant strategies and vegetation processes. John Wiley and Sons, Chichester, England. 222 pp.

Groh, H., and C. Frankton. 1949. Canadian weed survey. $7^{\text {th }}$ Report. Canada Department of Agriculture, Ottawa, Ontario. $144 \mathrm{pp}$.

Hume, L. 1982. The long-term effects of fertilizer application and three rotations on weed communities in wheat (after 21-22 years at Indian Head, Saskatchewan). Can. J. Plant Sci. 62 : 741-750.

Hume, L., and O.W. Archibold. 1986. The influence of a weedy habitat on the seedbank of an adjacent cultivated field. Can. J. Bot. 64 : 1879-1883.

Hume, L., S. Tessier, and F.B. Dyck. 1991 Tillage and rotation influences on weed community and composition in wheat (Triticum aestivum L.) in southwestern Saskatchewan. Can. J. Plant Sci. 71 : 783 789.

Izaurralde, R.C., N.G. Juma, W.B. McGill, D.S. Chanasyk, S. Pawluk, and M.J. Dudas. 1993. Performance of conventional and alternative cropping systems in cryoboreal subhumid central Alberta. J. Agric. Sci. $120: 33-41$

Johnson, G.A., D.A. Mortensen, and A.R. Martin. 1995. A simulation of herbicide use based on weed spatial distribution. Weed Res. 35 : 197-205.

Keddy, P.A. 1987. Beyond reductionism and scholasticism in plant community ecology. Vegetatio $69: 209-212$

Légère, A., C. Lemieux, R.R. Simard, and C. Lapierre. 1993. Response of weed communities to fertility and tillage. Pages 41-48 in: $8^{\text {th }}$ EWRS Symposium. Braunschweig.

Magurran, A.E. 1988. Ecological diversity and its measurement. Princeton Univ. Press, Princeton, New Jersey. 179 pp.

Mahn, E.G. 1984. Structural changes of weed communities and populations. Vegetatio $58: 79-85$. 
Moyer, J.R., E.S. Roman, C.W. Lindwall, and R.E. Blackshaw. 1994. Weed management in conservation tillage systems for wheat production in North and South America. Crop Prot. $13: 243-259$.

Noy-Meir, I., and E. van der Maarl. 1987. Relations between community theory anal$y$ sis in vegetation science: some historical perspectives. Vegetatio $69: 5-15$.

O'Donovan, J.T. 1996. Weed economic thresholds : useful agronomic tool or pipe dream ? Phytoprotection 77 : 13-28.

Salonen, J. 1993. Weed infestation and factors affecting weed incidence in spring cereals in Finland - a multivariate approach. Agric. Sci. Finland 2 (Suppl.) I: 1-11.

Swanton, C.J., D.R. Clements, and D.A. Derksen. 1993. Weed succession under conservation tillage : a hierarchical framework for research and management. Weed Technol. 7 : 286-297.

ter Braak, C.J.F. 1987. Ordination. Pages 91-173 in: R.H. Jongman, C.J.F. ter Braak, and O.F.R. Van Tongeren (eds.). Data Analysis in Community and Landscape Ecology. Pudoc, Wageningen.

Thomas, A.G. 1985. Weed survey system used in Saskatchewan for cereal and oilseed crops. Weed Sci. 33 : 34-43.

Thomas, A.T. 1991. Floristic composition and relative abundance of weeds in annual crops of Manitoba. Can. J. Plant Sci. 71 : 831-839.
Thomas, A.G., and D.I. Donaghy. 1991. A survey of the occurrence of seedling weeds in spring annual crops in Manitoba. Can. J. Plant Sci. $71: 811-820$.

Thomas, A.G., and J.A. Ivany. 1990. The weed flora of Prince Edward Island cereal fields. Weed Sci. 38 : 119-124.

Thomas, A.G., and R.F. Wise. 1987. Weed survey of Saskatchewan cereal and oilseed crops 1986. Weed Survey Ser. Publ. 87-1, $251 \mathrm{pp}$.

Thomas, A.G., and R.F. Wise. 1988. Weed survey of Manitoba cereal and oilseed crops 1986. Weed Survey Ser. Publ. 88-1, $201 \mathrm{pp}$.

Thomas, A.G., D.J. Doohan, and K.V. McCully. 1994. Weed survey of spring cereals in New Brunswick. Phytoprotection $75: 113-124$.

Topham, P.B., and H.M. Lawson. 1982. Measurement of weed species diversity in crop/weed competition studies. Weed Res. $22: 285-293$

Turkington, R. 1989. The growth, distribution, and neighbour relationships of Trifolium repens in a permanent pasture. $\mathrm{V}$. The coevolution of competitors. J. Ecol. $77:$ 717-733. 